\title{
Differential Processing of Proenkephalin-A by Human Peripheral Blood Monocytes and T Lymphocytes
}

\author{
Wietse Kuis, Peter M. Villiger, Hans-Georg Leser, and Martin Lotz \\ Department of Molecular and Experimental Medicine, Research Institute of Scripps Clinic, La Jolla, California 92037; \\ and Department of Medicine, University of California, La Jolla, California 92093
}

\begin{abstract}
Human peripheral blood mononuclear cells are analyzed for preproenkephalin gene expression and peptide processing.

Met-enkephalin immunoreactivity as detected with a specific antiserum is found in the cytoplasm of monocytes but not in $T$ lymphocytes. Secretion of met-enkephalin was analyzed with an RIA that is specific for the met-enkephalin pentapeptide. Unfractionated PBMC spontaneously released $40 \mathrm{pg} / \mathrm{ml}$ met-enkephalin and this increased two- to fourfold after stimulation with PHA. Lower levels $(<100 \mathrm{pg} / \mathrm{ml})$ of met-enkephalin were detected in supernatants from purified $T$ cells that were activated with PHA and IL-2. In contrast, stimulation of purified monocytes with LPS or PMA resulted in the release of up to $600 \mathrm{pg} / \mathrm{ml}$ of the processed peptide. To examine whether $T$ cells can produce met-enkephalin precursor peptides, $T$ cell conditioned media were treated with trypsin and carboxypeptidase-B, which is known to release met-enkephalin from the propeptide. This increased levels of met-enkephalin to $400 \mathrm{pg} /$ $\mathrm{ml}$, indicating that lymphocytes secrete the propeptide but do not process it to met-enkephalin. The 1.4-kb preproenkephalin mRNA is detected in activated blood mononuclear cells and in purified monocytes and $T$ cells.

To determine whether monocytes or lymphocytes express met-enkephalin in vivo, lymphoid tissues were analyzed by immunohistochemistry. In human spleen tissue, positive cells were found in the red pulp but not in the follicles, which is also consistent with met-enkephalin expression in monocytes.

In summary, these results show that human peripheral blood mononuclear cells express preproenkephalin mRNA and that monocytes, but not $\mathbf{T}$ cells, process the propeptide to metenkephalin. (J. Clin. Invest. 1991. 88:817-824.) Key words: enkephalins • monocytes • lymphocytes
\end{abstract}

\section{Introduction}

Neuropeptides represent one group of regulatory mediators that coordinate interactions between the nervous system and cells of the immune system (1). This has been demonstrated for

Address correspondence and reprint requests to Dr. M. Lotz, University of California, San Diego, SO45, La Jolla, CA 92093.

Received for publication 13 September 1990 and in revised form 5 March 1991.

J. Clin. Invest.

(c) The American Society for Clinical Investigation, Inc.

0021-9738/91/09/0817/08 $\$ 2.00$

Volume 88, September 1991, 817-824 peptides that are present in peripheral nerves (2) but also for the endogenous opioids (3). The mature pentapeptide met-enkephalin caused functional and phenotypic changes in T lymphocytes. Wybran et al. first demonstrated an increase in active $T$ rosette formation (4). A series of subsequent studies showed that met-enkephalin influences specific immunity through the stimulation of human $T$ cell migration (5), augmentation of peripheral blood lymphocyte proliferation (6), and through inhibition of primary and secondary antibody synthesis in vitro $(7,8)$. In addition, enkephalins were shown to stimulate nonspecific effector functions such as chemotaxis (9), superoxide production (10), antibody-dependent cellular cytotoxicity (ADCC) (10), and NK cell function (11). The discovery of opioid receptors on $\mathrm{T}$ lymphocytes and monocytes provided a structural basis for their ability to modulate cell functions (3). Depending on its cellular origin, met-enkephalin can influence the immune system in an endocrine, paracrine, or autocrine way. The major sites of met-enkephalin production in the neuroendocrine system are brain, spinal cord and sympathic ganglia, and the adrenal medulla (12). The finding that cells of the immune system may be capable of producing met-enkephalin provides the basis for paracrine or autocrine effects. The expression of preproenkephalin A mRNA in an activated mouse T-helper cell line at high levels comparable to those of typical T cell specific products such as interleukin-2, indicated that immune cells may be significant producers of enkephalin-like substances (13). Preproenkephalin mRNA was also found in activated murine $B$ cells from spleen, bone marrow, lymph node, and in murine macrophages $(14,15)$.

Although these results clearly document that the preproenkephalin gene can be transcribed in cells of the immune system, it is not known which products are generated from the precursor protein proenkephalin A. It has been suggested that $T$ helper cells only secrete intermediate higher molecular weight enkephalin-like peptides, and that processing to metenkephalin does not take place (16). The peptides secreted by monocytes have not been analyzed. This study was designed to investigate which cells among human peripheral blood mononuclear cells express the preproenkephalin A mRNA, how this is regulated, and which peptides are produced. Proenkephalin A mRNA was found in activated peripheral blood $T$ cells and monocytes, but the two cell types are characterized by differential processing of the propeptide.

\section{Methods}

Cell isolation. PBMC from healthy adults were isolated by Ficoll-Hypaque density gradient centrifugation of heparinized blood. T cells $\left(\mathrm{E}^{+}\right)$ and non- $T$ cells $\left(E^{-}\right)$were purified by rosetting with 2-amino-ethylisothiouronium (AET)-treated sheep erythrocytes. Monocytes were iso- 
lated from mononuclear cell suspensions by adherence to plastic (Falcon Flasks, Becton Dickinson Co., Lincoln Park, NJ) at $37^{\circ} \mathrm{C}$ in RPMI 1640 medium, supplemented with $10 \%$ autologous plasma.

Culture conditions. PBMC and peripheral blood T cells were cultured with PHA (1\% vol/vol) (Difco) and IL-2 (Cetus Corp., Emeryville, $C A$ ) in RPMI 1640 with $5 \%$ heat inactivated FBS at a cell concentration of $1 \times 10^{6}$ cells/ml per well in 24-well tissue culture plates (Costar Corp., Cambridge, MA). Macrophage plates were incubated in a humidified atmosphere containing $5 \% \mathrm{CO}_{2}$ at $37^{\circ} \mathrm{C}$ for up to $3 \mathrm{~d}$. Analysis of the time kinetics showed that maximal secretion of met-enkephalin was reached by $24 \mathrm{~h}$ and this time point was thus studied in al subsequent experiments. Monocytes were resuspended in RPMI 1640 supplemented with $5 \%$ heat inactivated FBS at $10^{6} / \mathrm{ml}$ and stimulated with PMA $(1-5 \mathrm{ng} / \mathrm{ml})$ or LPS $(100 \mathrm{pg}-10 \mu \mathrm{g} / \mathrm{ml})$.

Immunohistochemistry. Cells were recovered from the tissue culture plates, washed in PBS, and cytocentrifuge preparations of mononuclear cells were prepared in a Shandon-Elliott centrifuge (Shandon Southern, Astmoor, Runcorn, Cheshire, England) (500-700 rpm for 5 $\mathrm{min}$ ) from $150 \mu \mathrm{l}$ of the washed cell suspension $\left(10^{6} / \mathrm{ml}\right)$. Monocytes were cultured and stained on tissue culture chamber slides (Nunc, Inc., Naperville, IL). The cells were fixed in a mixture of $99 \%$ ethanol and $1 \%$ acetic acid for $20 \mathrm{~min}$ at $4^{\circ} \mathrm{C}$. Monocytes were treated with a blocking serum (preimmune goat serum, $1 / 400$ dilution) for $20 \min (50 \mu \mathrm{l})$. The cells were incubated at $4^{\circ} \mathrm{C}$ in humidified chambers for $2 \mathrm{~h}$ with rabbit antibody to met-enkephalin (Incstar, Stillwater, MN) at dilutions of $1 / 100-1 / 500$. This rabbit antiserum was raised against met-enkephalin conjugated to bovine thyroglobulin. The slides were then washed by dipping 20 times in cold PBS. Secondary biotinylated antibody (Vector Laboratories, Burlingame, CA; $1 / 300,50 \mu \mathrm{l}$ ) and the avidin-peroxidase complex ( $15 \mu \mathrm{l} / \mathrm{ml}$ PBS, $50 \mu \mathrm{l})$ were applied for 45 min each. The slides were developed with freshly prepared substrate (3-amino, 9-ethyl carbazole; Biomeda Corp., Foster City, CA). The cells were counterstained with hematoxylin.

Immunostaining of tissue. Lymphoid tissues were obtained at surgery and snap frozen in liquid nitrogen. Frozen tissue sections $(5 \mu \mathrm{m})$ were incubated with a blocking serum (preimmune goat serum, 1/400 dilution) for $30 \mathrm{~min}$. The blocking agent was removed and the slides were incubated for 16-24 h with rabbit antibody to met-enkephalin (Incstar) at dilutions of 1/100-1/500. Incubation with biotinylated secondary antibody and avidin-peroxidase were performed as described above.

Radioimmunoassay. Met-enkephalin in the conditioned media from PBMC and isolated subsets was quantified by RIA (Incstar). The cross-reactivity of the antibody used in this assay with other products of the preproenkephalin gene or other neuropeptides is $<3 \%$, except for peptide $F(22 \%)$ (17).

Culture supernatants (1-ml aliquots) were acidified with $100 \mu \mathrm{l}$ of 1 $\mathrm{mM} \mathrm{HCl}$ and extracted with ODS silica columns (Immunonuclear Corp.). The columns were washed with $20 \mathrm{ml}$ of $4 \%$ acetic acid, eluted with $4 \mathrm{ml} 99.8 \%$ methanol, and the eluates were lyophilized. Duplicate samples of dried eluates were resuspended in bovine serum albuminphosphate buffer before the assay. In some experiments, the dried eluates were resuspended in Tris-buffer ( $\mathrm{pH} 8.5$ ) with $0.2 \%$ bovine serum albumin and digested with L-1-Tosylamide-2-phenylethyl chloro-methyl ketone (TPCK) ${ }^{1}$-treated trypsin $(1 \mu \mathrm{g}$ trypsin/200 $\mu \mathrm{l})$ for $16 \mathrm{~h}$ at $37^{\circ} \mathrm{C}$, followed by treatment with carboxypeptidase $\mathrm{B}(0.1 \mu \mathrm{g} /$ $200 \mu \mathrm{l})$ for $2 \mathrm{~h}$ at $37^{\circ} \mathrm{C}$. To inactivate the enzyme the supernatants were treated for $20 \mathrm{~min}$ at $90^{\circ} \mathrm{C}$. The samples were then tested in the met-enkephalin radioimmunoassay.

Met-enkephalin concentrations in the culture supernatants were calculated on the basis of a standard curve using synthetic met-enkephalin $(10 \mathrm{pg}-2.5 \mathrm{ng})$ that was included in each assay.

1. Abbreviations used in this paper: TPCK, L-1-Tosylamide-2-phenylethyl chloro-methyl ketone.
$R N A$ probe preparation. The human preproenkephalin cDNA was kindly provided by Dr. M. Coomb (Harvard Medical School, Boston, MA). As suitable restriction sites for subcloning are lacking at the 3'end of the cDNA, a 926-bp fragment was amplified by polymerase
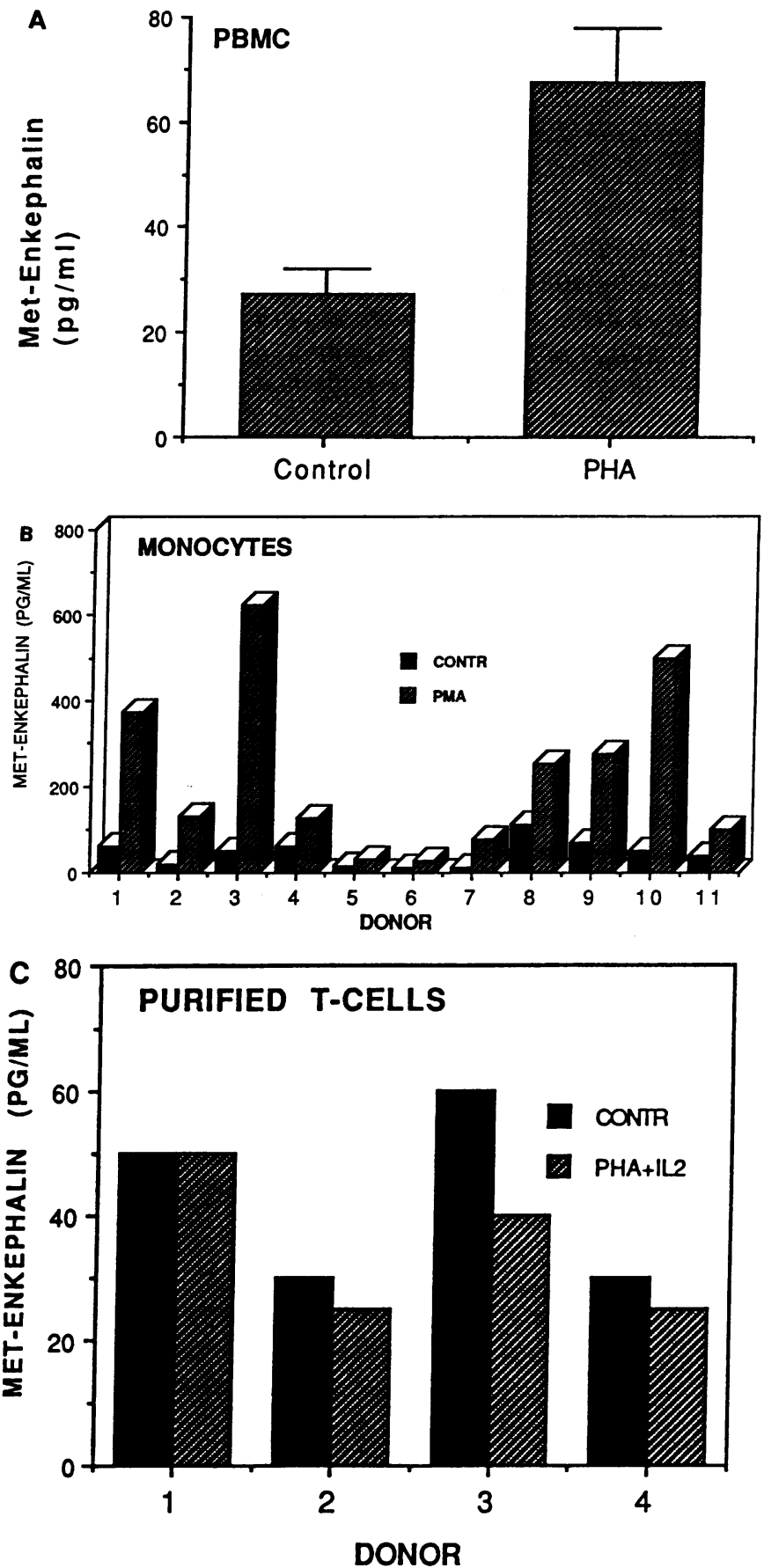

Figure 1. Release of met-enkephalin from PBMC and purified monocytes and $\mathrm{T}$ cells. Unseparated PBMC were stimulated with PHA ( $1 \% \mathrm{vol} / \mathrm{vol})$ for $3 \mathrm{~d}(A)$. Purified blood monocytes $(B)$ were stimulated for $24 \mathrm{~h}$ with PMA $(5 \mathrm{ng} / \mathrm{ml})$. Purified peripheral blood T cells $(C)$ were cultured in the absence of presence of PHA and IL-2 for $3 \mathrm{~d}$. All populations were cultured at the same cell density $\left(10^{6} /\right.$ $\mathrm{ml}$ ). Supernatants of stimulated as well as unstimulated (control) cells were analyzed by a RIA for met-enkephalin. Values represent mean \pm SEM of four experiments each performed in duplicate. 

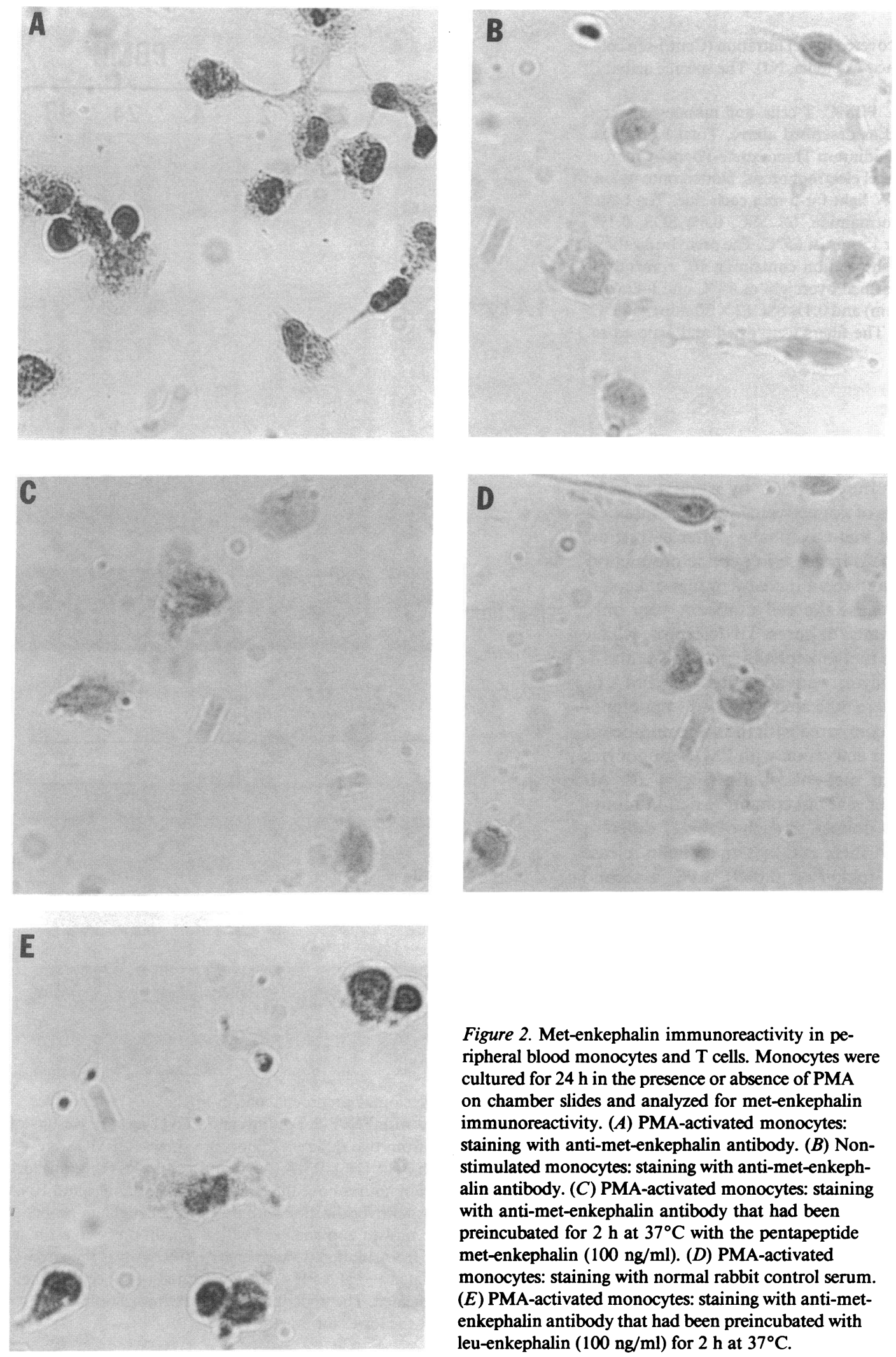

Figure 2. Met-enkephalin immunoreactivity in peripheral blood monocytes and $\mathrm{T}$ cells. Monocytes were cultured for $24 \mathrm{~h}$ in the presence or absence of PMA on chamber slides and analyzed for met-enkephalin immunoreactivity. (A) PMA-activated monocytes: staining with anti-met-enkephalin antibody. $(B)$ Nonstimulated monocytes: staining with anti-met-enkephalin antibody. $(C)$ PMA-activated monocytes: staining with anti-met-enkephalin antibody that had been preincubated for $2 \mathrm{~h}$ at $37^{\circ} \mathrm{C}$ with the pentapeptide met-enkephalin $(100 \mathrm{ng} / \mathrm{ml})$. (D) PMA-activated monocytes: staining with normal rabbit control serum. (E) PMA-activated monocytes: staining with anti-metenkephalin antibody that had been preincubated with leu-enkephalin $(100 \mathrm{ng} / \mathrm{ml})$ for $2 \mathrm{~h}$ at $37^{\circ} \mathrm{C}$.

chain reaction (18). The primers $\left(5^{\prime}\right.$ GC GAATTC CGACGAGTCGTGTCT 3'; and 3' AGGTAGGAGGTCACC TTCGAA CG $\left.5^{\prime}\right)$ define the open reading frame and contain the restriction sites EcoRI and HindIII, respectively. The fragment was ligated into the polylinker site of the transcription vector pGEM-4z (Promega Corp. Madison, WI). For hybridization, the recombinant plasmid was linearized with an appropriate restriction enzyme and transcribed with the $\mathrm{T} 7$ polymerase in the presence of $\left[{ }^{32} \mathrm{P}\right]$ UTP (Riboprobe system; Pro- 
mega Corp.). The probe was recovered by gel filtration (Centri-sep columns; Princeton Separations Inc., Adelphia, NJ). The specific activity was $\sim 2 \times 10^{8} \mathrm{cpm} / \mu \mathrm{g}$ template.

Northern blot hybridization. PBMC, T cells, and monocytes were isolated, purified, and cultured as described above. Total RNA was extracted by the single step Guanidinium Thiocyanate-Phenol-Chloroform method (19), analyzed by gel electrophoresis, blotted onto nylon filters, and cross-linked with UV light for 5 min each side. The blots were prehybridized in $50 \%$ Formamide, $6 \times$ SSC, $0.5 \%$ SDS, $0.1 \%$ Tween $20,100 \mu \mathrm{g}$ tRNA/ml for $15 \mathrm{~min}$ at $65^{\circ} \mathrm{C}$. The prehybridization mixture was replaced with fresh solution containing $10^{6} \mathrm{cpm} / \mathrm{ml}$ of probe. Hybridization was performed overnight at $65^{\circ} \mathrm{C}$ and followed by washes in $1 \times \operatorname{SSC}(2 \times 30 \mathrm{~min})$ and $0.1 \times \operatorname{SSC}(2 \times 30 \mathrm{~min})$ at $65^{\circ} \mathrm{C}$ in the presence of $0.1 \%$ SDS. The filters were dried and exposed to Kodak XAR film at $-70^{\circ} \mathrm{C}$.

\section{Results}

Met-enkephalin secretion by PBMC. Met-enkephalin was measured in supernatants of cultured PBMC by using a specific RIA (Fig. $1 A$ ). Supernatants of nonactivated PBMC contained low levels $(<100 \mathrm{pg} / \mathrm{ml})$ of met-enkephalin. After activation with PHA, a maximal fourfold increase in peptide production was observed. This was related to an increase in met-enkephalin production per cell because the cell numbers were only $11 \pm 3 \%$ higher in PHA-activated cultures. To determine which cells among PBMC produce met-enkephalin, monocytes and T cells were separated. Monocytes were activated with PMA (1 $\mathrm{ng} / \mathrm{ml}$ ) and supernatants were collected after $24 \mathrm{~h}$. Spontaneous secretion was higher as compared with the same number of unfractionated PBMC. After activation with PMA, monocytes secreted increased levels of met-enkephalin (Fig. 1 B). Although the absolute levels of met-enkephalin varied in monocyte cultures from different donors, in each of the 11 different normal donors tested, PMA increased met-enkephalin release (mean increase 5.06 \pm 3.56 -fold, $P<0.009$ ). LPS, a second monocyte activator, also induced met-enkephalin secretion (data not shown).

In purified populations of $\mathrm{T}$ lymphocytes there was only very low spontaneous secretion of met-enkephalin. Even after incubation in the presence of PHA and IL-2, a combination of stimuli that induces maximal proliferation of the cells, we did not detect an increase in peptide release (Fig. $1 C$ ).

Detection of met-enkephalin immunoreactivity in PBMC. To consolidate these findings on peptide secretion by monocytes with detection of intracellular met-enkephalin and to exclude the possibility that lymphocytes may synthesize, but not secrete the peptide in culture, immunohistochemistry was performed on peripheral blood monocytes and $\mathrm{T}$ cells. Monocytes showed cytoplasmatic staining after PMA activation (Fig. $2 \mathrm{~A}$ ). Maximal expression of met-enkephalin immunoreactive material was seen after $24 \mathrm{~h}$. At that time point, up to $90 \%$ of the activated cells were positive. In nonstimulated monocyte cultures less than $15 \%$ of the cells showed cytoplasmic staining with a lower intensity (Fig. $2 \mathrm{~B}$ ). Specificity of the staining was demonstrated by blocking the antibody with pentapeptide metenkephalin (Fig. $2 C$ ) and by negative staining with normal rabbit serum (Fig. $2 \mathrm{D}$ ). Under these conditions, no positive cytoplasmatic staining was seen. Furthermore, preincubation of the antiserum with leu-enkephalin did not abrogate the staining (Fig. $2 E$ ).
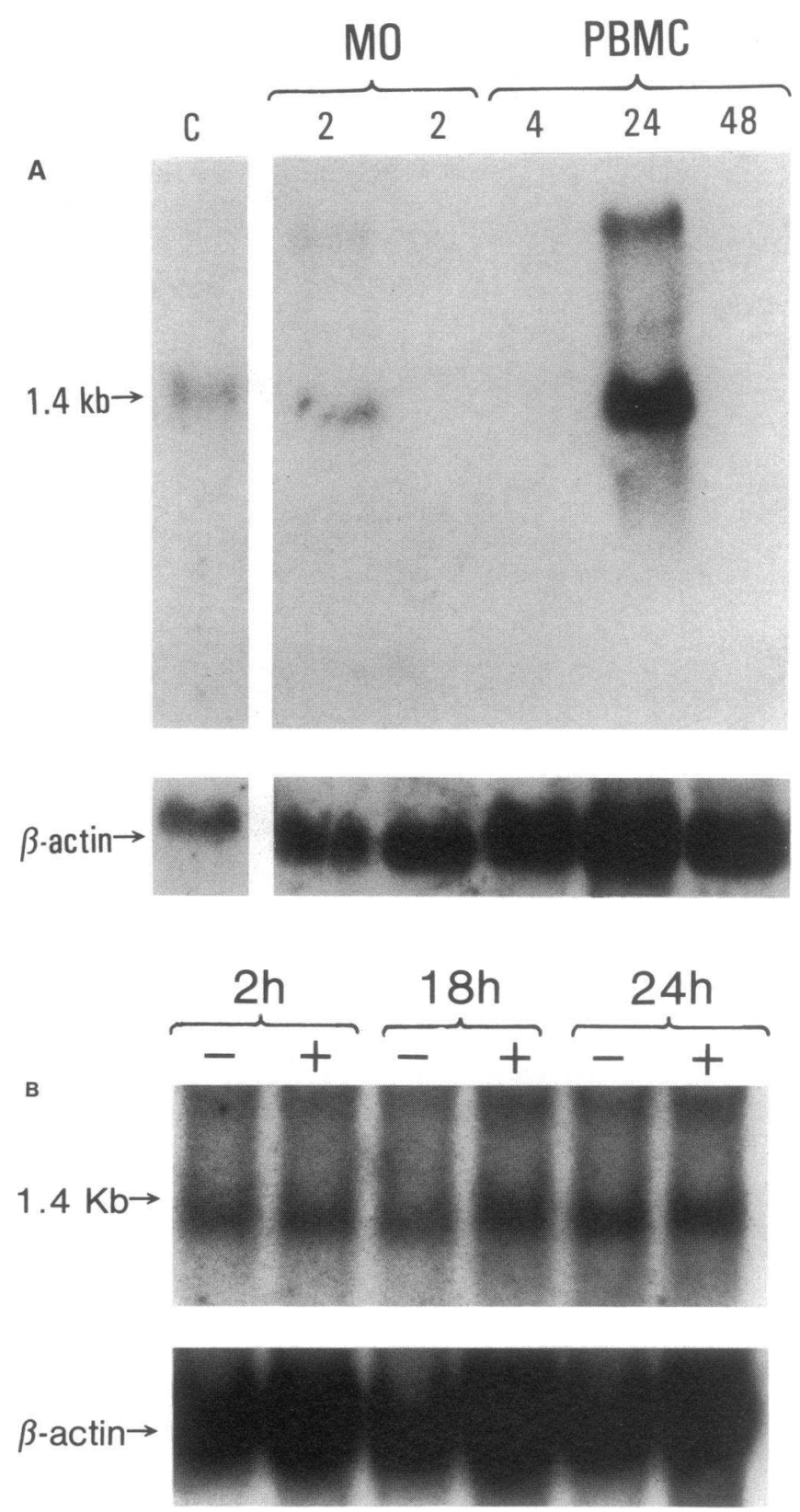

Figure 3. Expression of preproenkephalin mRNA. $(A)$ Monocytes were stimulated with PMA $(2.5 \mathrm{ng} / \mathrm{ml})$ and LPS $(1 \mu \mathrm{g} / \mathrm{ml})$. Results of activated cells from two different donors are shown. PBMC were stimulated with PHA (1\%), PMA $(2.5 \mathrm{ng} / \mathrm{ml})$, and LPS $(1 \mu \mathrm{g} / \mathrm{ml})$ for times indicated in hours above the lanes. As a control, rat brain RNA $(C)$ was used. After hybridization with the preproenkephalin probe, the filters were washed and analyzed with a $\beta$-actin probe to estimate the amount of RNA blotted (lower panel). (B) RNA was prepared from unstimulated $(-)$ and PHA/PMA-activated $(+)$ T cells at the time points indicated. The upper panel shows hybridization for preproenkephalin, the lower for $\beta$-actin.

In contrast to the staining of monocytes, stimulated as well as nonstimulated T cells (PHA + IL-2 for 1-3 d) did not contain detectable cytoplasmic met-enkephalin immunoreactive material (not shown). 

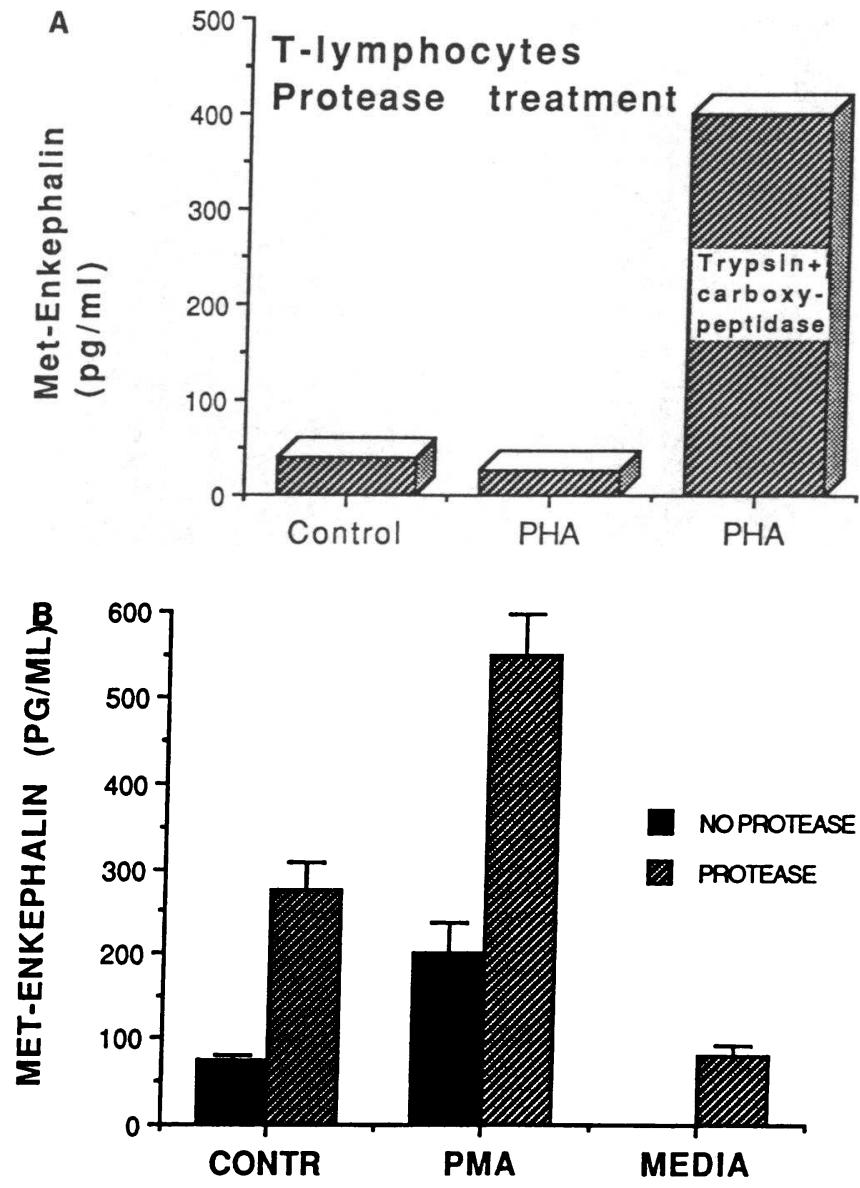

Figure 4. Detection of met-enkephalin in supernatants of peripheral blood monocytes and $\mathrm{T}$ cells following protease treatment. Peripheral blood T cells ( $\mathrm{E}^{+}$cells) $(A)$ were cultured for $3 \mathrm{~d}$ with PHA and IL-2. Peripheral blood monocytes $(B)$ were cultured for $24 \mathrm{~h}$ with PMA. The supernatants of activated as well as control cells were digested with TPCK-treated trypsin and carboxypeptidase B. The supernatants were then analyzed by RIA for met-enkephalin. Results represent two $(A)$ and three $(B)$ experiments and are shown as mean \pm SEM.

Expression of preproenkephalin $m R N A$ in $P B M C$. To investigate whether the absence of met-enkephalin immunoreactive material in activated $T$ cells was due to incomplete processing of the prepropeptide or due to absent transcription or translation, RNA was isolated from unseparated PBMC, T cells, and monocytes and analyzed by Northern blotting (Fig. 3). Activated PBMC showed a strong hybridization signal at $1.4 \mathrm{~kb}$, which is consistent with the size of mature preproenkephalin mRNA. Maximal expression in unfactionated PBMC was seen at $24 \mathrm{~h}$. Purified monocytes express this mRNA very early $(2 \mathrm{~h})$ and as with the titers of secreted peptides there was also donor variability in mRNA levels (Fig. $3 A$ ). Experiments with purified $\mathrm{T}$ cells (Fig. $3 B$ ) showed that these cells also express the preproenkephalin RNA by $2 \mathrm{~h}$ and that maximal expression after stimulation occurs by $24 \mathrm{~h}$. The $24 \mathrm{~h}$ signal in PBMC was thus probably due to met-enkephalin expression by $\mathrm{T}$ cells. Possible interactions between monocytes and $T$ cells may contribute to higher levels of RNA and changes in kinetics in unseparated PBMC as compared with the purified subpopulations.
Secretion of the enkephalin propeptide. The results presented above indicated that activated $T$ cells express proenkephalin mRNA, but that processing to the pentapeptide met-enkephalin may not occur. It was thus possible that activated $T$ cells secrete higher molecular weight enkephalin precursors. From these precursors met-enkephalin can be generated by in vitro treatment with proteases (20). Supernatants from PHA/ IL-2-activated $T$ cells were assayed for met-enkephalin before and after digestion with trypsin and carboxypeptidase B. As shown earlier, the untreated $T$ cell supernatants contained only very low levels of met-enkephalin. After enzymatic digestion of aliquots from the same $T$ cell conditioned media, met-enkephalin was detected in concentrations up to $400 \mathrm{pg} / \mathrm{ml}$ (Fig. $4 \mathrm{~A}$ ). Protease treatment of nonconditioned culture media resulted in the detection of $80 \mathrm{pg} / \mathrm{ml}$ of met-enkephalin which probably originated from FBS that was present in the culture media.

Similar experiments with monocyte conditioned media showed that these cells also secrete precursor molecules (Fig. 4 $B)$. Precursor secretion was detected in unstimulated monocytes and at higher levels after PMA stimulation. The finding that nonactivated monocytes secrete detectable levels of the precursor molecules raised the possibility that the cells may contain a cytoplasmatic store of the propeptides similar to cells of the neuroendocrine system (21). To test this notion, cultures of monocytes were performed in the presence of actinomycin$D$ or cyclohexamide. These agents did not reduce the secretion of the propeptide by nonactivated monocytes. However, actinomycin or cyclohexamide reduced propeptide production by stimulated cells to levels found in the unstimulated cultures (Fig. 5). These results indicate that monocytes store and release detectable levels of met-enkephalin precursors and that the increase observed after stimulation of the cells is related to increased transcription and translation.

Detection of met-enkephalin immunoreactive cells in vivo. Having shown that monocytes produce met-enkephalin in vi-

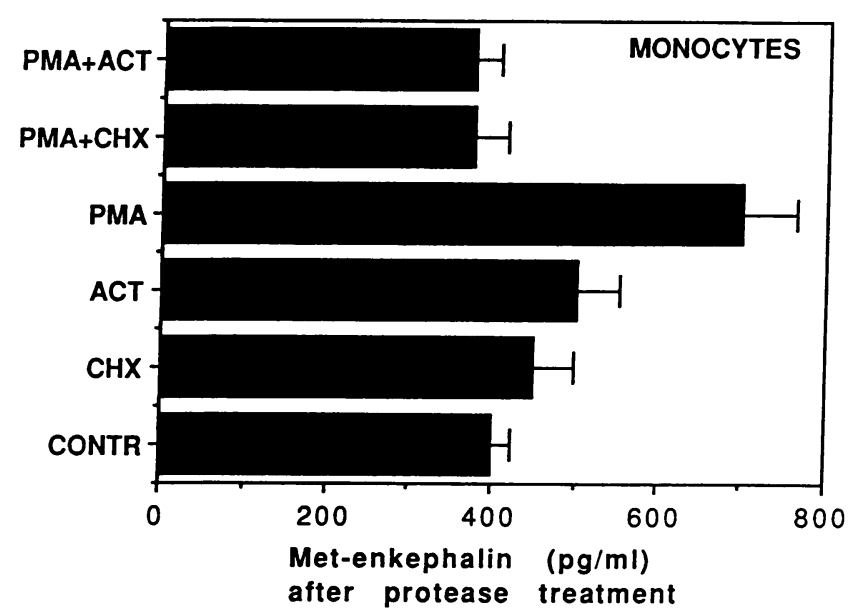

Figure 5. Effect of actinomycin D and cyclohexamide on the release of the precursor of met-enkephalin. PMA activated monocytes and unstimulated monocytes were cultured with actinomycin or cyclohexamide for $24 \mathrm{~h}$. The supernatants were treated with TPCK-treated trypsin and carboxypeptidase B, and met-enkephalin immunoreactive material was quantified by RIA. Results from one of three representative experiments are shown. 

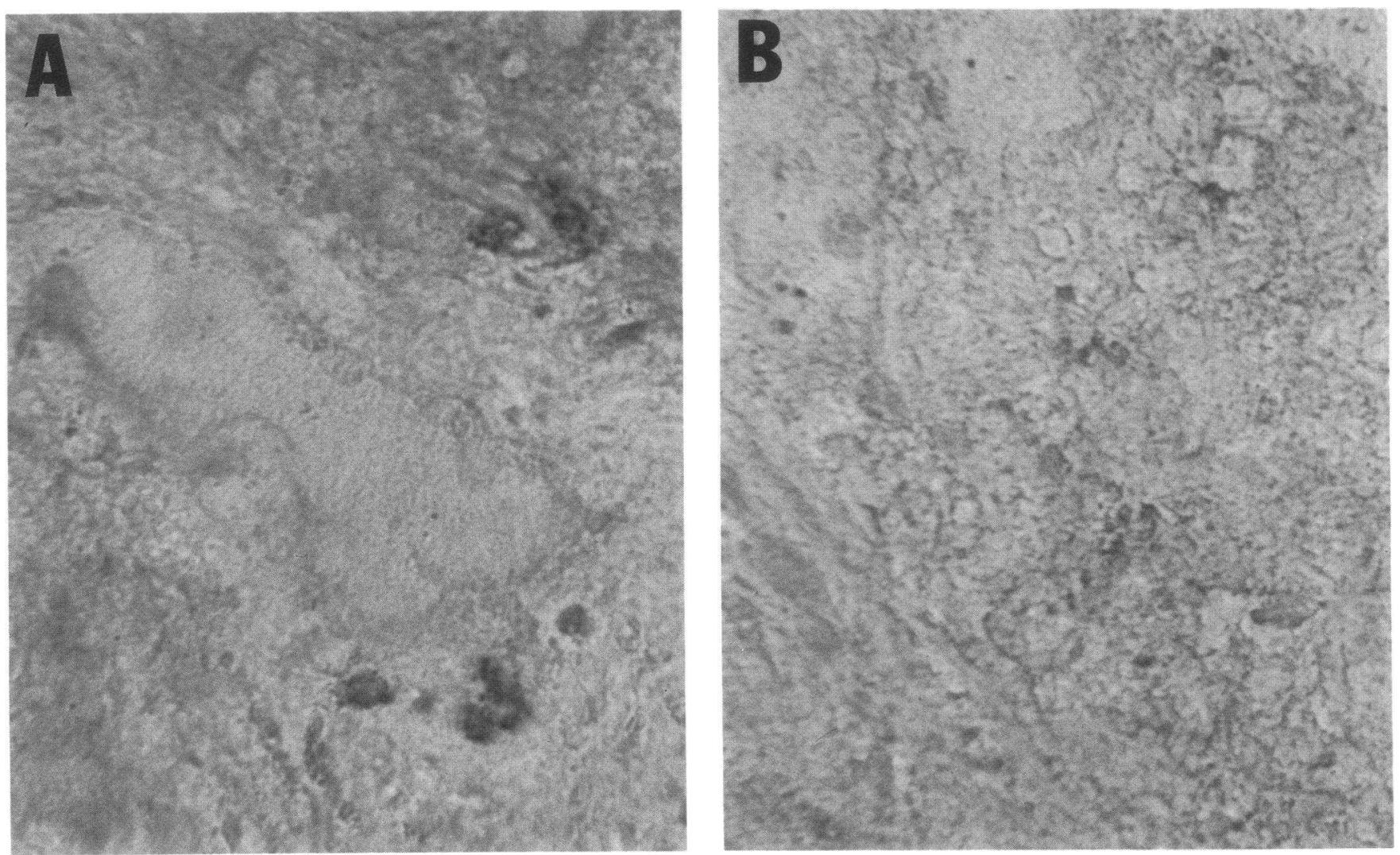

Figure 6. Expression of met-enkephalin immunoreactivity in human spleen tissue. Frozen tissue sections of human spleen were analyzed by immunohistochemistry for met-enkephalin immunoreactivity. $(A)$ Staining with antibody to met-enkephalin. (B) Staining with antibody to met-enkephalin that had been preincubated with met-enkephalin $(100 \mathrm{ng} / \mathrm{ml})$ for $2 \mathrm{~h}$ at $37^{\circ} \mathrm{C}$.

tro we studied whether lymphoid cells express the peptide in vivo. Frozen sections of human spleen were analyzed by immunohistochemistry for the presence of met-enkephalin (Fig. 6). Met-enkephalin immunoreactive cells were seen in the red pulp, but not in the follicles, which is consistent with the anatomical distribution of macrophages. Specificity of the staining was demonstrated by blocking with met-enkephalin and the absence of staining with normal rabbit serum. Staining of human tonsil showed a similar pattern with positive cells in the parafollicular areas but not within the follicles (not shown).

\section{Discussion}

This study examines preproenkephalin gene expression, propeptide synthesis, processing, and secretion of met-enkephalin by human peripheral blood monocytes and $T$ lymphocytes.

Preproenkephalin mRNA is detected at low levels in resting cells and expression is increased after activation of monocytes and $T$ cells. Maximal expression of mRNA in monocytes is more rapid as compared with purified $T$ cells. With these characteristics the preproenkephalin gene in monocytes and $\mathrm{T}$ cells is regulated similar to other genes encoding secretory products in cells of the immune system. The size of the preproenkephalin mRNA is identical in human monocytes and T cells and similar to that in rat brain. Expression of the preproenkephalin gene by cells of the immune system had previously been studied in a mouse T-helper cell line where it was found to be present in quantities similar to those of IL-2 (13). In subsequent studies it was found that this mRNA is preferentially expressed in type 1 helper $T$ cells and at lower levels in type 2 cells. This paper is the first description of preproenkephalin mRNA in primary $T$ cells and human monocytes. These results are consistent with the findings in murine $T$ cell lines and with the observations in murine macrophage cell lines and activated peritoneal macrophages (15).

Having shown that human monocytes and $T$ cells express the preproenkephalin mRNA, we analyzed the enkephalin peptides that are present intracellularly and in the conditioned media of cultured cells. By immunohistochemistry we found intracellular met-enkephalin immunoreactive material in monocytes, but not in $\mathrm{T}$ cells. The immunoreactivity increased after activation of monocytes. These experiments were performed with an antiserum raised against synthetic met-enkephalin conjugated to bovine thyroglobulin. Specificity was confirmed because the antibody reactivity was blocked by met-enkephalin but not by leu-enkephalin. It is thus possible that the staining detected in monocytes represents intracellular stores of met-enkephalin or of precursors that express epitopes recognized by the antiserum. Precursors that may show cross-reactivity with met-enkephalin include predominantly peptide $F$ which contains a met-enkephalin sequence at the carboxyl ter- 
minus (22). The lack of staining in $\mathrm{T}$ cells indicates that these cells only produce proenkephalin A or process the propeptide to larger molecular weight intermediates that are not recognized by the antiserum. Similar differences that are at least in part related to the extent of intracellular processing were found in the met-enkephalin immunoreactive material secreted by monocytes and $T$ cells. Conditioned media from monocytes contains peptides that are either completely processed met-enkephalin and/or peptide $F$. In addition, other precursor molecules are secreted by monocytes and are detectable as met-enkephalin immunoreactive material after in vitro hydrolysis. These precursors include the noncross-reactive peptides I, B, and $E$, and proenkephalin A. Secretion of these precursors is also increased after monocyte activation. In contrast to monocytes, there was no met-enkephalin immunoreactivity in native conditioned media from $T$ cells. However, treatment of $T$ cell supernatants with trypsin and carboxypeptidase $B$ generated high levels of met-enkephalin immunoreactive material. This in vitro treatment has been shown to result in the production of the pentapeptide (20), but it is possible that incompletely processed peptide $\mathrm{F}$ may also contribute to the immunoreactivity detected in this study (17). Studies on murine helper T cell lines have shown the production predominantly of high molecular weight material (16). The presence of the precursor molecule in the conditioned media from nonstimulated monocytes can be explained by storage and release of constitutively produced precursor. The levels of peptide in supernatants of nonstimulated monocytes is not influenced by cyclohexamide and actinomycin-D, also suggesting intracytoplasmic storage of the peptide. The levels of precursor molecules secreted by monocytes were higher in monocytes than in $\mathrm{T}$ cells. This is consistent with the function of monocytes as secretory cells and may also be related to the use of monocyte activators that stimulate secretory function and proliferative agents for $\mathrm{T}$ cells.

Differences in proenkephalin precursors as reported here for monocytes and $T$ cells have previously been described between neural and adrenal tissues. The profile of enkephalin products from monocytes is more closely related to that found in neural tissues that generate lower molecular weight products, while that of $\mathrm{T}$ lymphocytes resembles more adrenal cells which secrete larger amounts of higher molecular weight precursor proteins (12). In this context it is of interest that the distribution of met-enkephalin immunoreactive cells in human spleen is almost identical to the distribution of cells that express endorphins in murine spleen. Furthermore, splenic macrophages express the mRNA for proopiomelanocortin and process the polyvalent precursor protein to mature opioid-active peptides. In contrast, splenic lymphocytes do not express these peptides $(23,24)$. Collectively these observations may indicate that monocytes, but not lymphocytes, are able to process the large molecular weight precursors of neuropeptides. This may be related to the presence of processing enzymes in monocytes but not in $\mathrm{T}$ cells. Detailed analysis of this notion will be possible once met-enkephalin processing enzymes have been completely characterized.

The precursor molecules secreted by $\mathrm{T}$ cells may represent a source of peptide that is more stable and rapidly activated. Relatively high levels of met-enkephalin reactivity are found in plasma (17). In addition to the nervous system, adrenal gland, and the gut $(12,25)$, it is conceivable that cells of the immune system contribute to this circulating pool. Alternatively, the incompletely processed precursor may be functionally active. This has already been shown for some of the precursor forms that have very high affinity for opioid receptors (26). The possibility that these proteins can regulate immune responses is under investigation.

A potential role of the met-enkephalin pentapeptide produced by activated monocytes may be to influence immunological and inflammatory effector functions. It stimulates specific as well as nonspecific cytotoxicity and oxygen dependent killing in neutrophils and monocytes $(6-8,10,11)$. In addition, met-enkephalin is a chemotactic factor for T lymphocytes (5) and monocytes (9). This may indicate that met-enkephalin produced at sites of inflammation promotes the influx of immune cells. In agreement with this concept are the recent findings by Saland and co-workers (27), that endogenous opoids such as $\alpha$ - and $\beta$-endorphin and met-enkephalin, administered to the lateral ventricle of rats, caused an influx of leukocytes.

It is also possible that enkephalins produced by cells of the immune system act on opioid receptors expressed in the nervous system or modulate functions of connective tissue cells (28). Met-enkephalin produced by cells of the immune system may, thus, not only modulate immune functions but contribute to the regulation of local and systemic aspects of host defense responses.

\section{Acknowledgments}

We thank Mrs. J. A. Shin for expert technical assistance.

This work was supported by the Office of Naval Research (ONR N00014-90-J-1637) and the Swiss National Science Foundation (81 BE-20628). Dr. Lotz is the recipient of an Investigator Award from the Arthritis Foundation.

\section{References}

1. Weigent, D. A., and J. E. Blalock. 1987. Interactions between the neuroendocrine and immune systems: common hormones and receptors. Immunol. Rev. 100:79-108.

2. Morley, J. E., N. E. Kay, G. F. Solomon, and N. P. Plotnikoff. 1987. Neuropeptides: conductors of the immune orchestra. Life Sci. 41:527-544.

3. Sibinga, N. E. S., and A. Goldstein. 1988. Opioid peptides and opioid receptors in cells of the immune system. Annu. Rev. Immunol. 6:219-249.

4. Wybran, J., T. Appelboom, J. P. Famaey, and A. Govaerts. 1979. Suggestive evidence for receptors for morphine and methionine-enkephalin on normal human blood T lymphocytes. J. Immunol. 123:1068-1070.

5. Heagy, W., M. Laurance, E. Cohen, and R. Finberg. 1990. Neurohormones regulate T cell function. J. Exp. Med. 171:1625-1633.

6. Hucklebridge, F. H., B. N. Hudspith, P. M. Lydyard, and J. Brostoff. 1990. Stimulation of human peripheral lymphocytes by methionine enkephalin and $\delta$-selective opioid analogues. Immunopharmacology. 19:87-91.

7. Johnson, H. M., E. M. Smith, B. A. Torres, and J. E. Blalock. 1982. Regulation of the in vivo antibody response by neuroendocrine hormones. Proc. Natl. Acad. Sci. USA. 79:4171-4174.

8. Munn, N. A., and L. G. Lum. 1989. Immunoregulatory effects of $\alpha$-endorphin, $\beta$-endorphin, methionine-enkephalin and adrenocortico-tropic hormone on anti-tetanus toxoid antibody synthesis by human lymphocytes. Clin. Immunol. Immunopathol. 52:376-385.

9. Van Epps, D. E., and L. Saland. 1984. $\beta$-endorphin and met-enkephalin stimulate human peripheral blood mononuclear cell chemotaxis. J. Immunol. 132:3046-3053.

10. Foris, G., G. A. Medgyesi, E. Gyimesi, and M. Hauck. 1984. Met-enkephalin induced alterations of macrophage functions. Mol. Immunol. 21:747750.

11. Faith, R. E., H. J. Liang, A. J. Murgo, and N. P. Plotnikoff. 1984. Neuroimmunomodulation with enkephalins: enhancement of human natural killer (NK) cell activity in vitro. Clin. Immunol. Immunopathol. 31:412-418.

12. Clement-Jones, V., and G. M. Besser. 1984. Opioid peptides in humans and their clinical significance. Peptides. 6:323-371. 
13. Zurawski, G., M. Benedik, B. J. Kamb, J. S. Abrams, S. M. Zurawski, and F. D. Lee. 1986. Activation of mouse T-helper cells induces abundant preproenkephalin mRNA synthesis. Science (Wash. DC). 232:772-775.

14. Rosen, H., O. Behar, O. Abramsky, and H. Ovadia. 1989. Regulated expression of proenkephalin A in normal lymphocytes. J. Immunol. 143:37033707.

15. Martin, J., M. B. Prystowsky, and R. H. Angeletti. 1987. Preproenkephalin mRNA in T cells, macrophages, and mast cells. J. Neurosci. 18:82-87.

16. Roth, K. A., R. G. Lorenz, R. A. Unanue, and C. T. Weaver. 1989. Nonopiate active proenkephalin-derived peptides are secreted by $\mathrm{T}$ helper cells. FASEB (Fed. Am. Soc. Exp. Biol.) J. 3:2401-3407.

17. Pierzchala, K., and G. R. Van Loon. 1990. Plasma native and peptidasederivable met-enkephalin responses to restraint stress in rats. J. Clin. Invest. 85:861-873.

18. Mullis, K., F. Faloona, S. Scharf, R. Saiki, G. Horn, and H. Ehrlich. 1986. Specific enzymatic amplification of DNA in vitro: the polymerase chain reaction. Cold Spring Harbor Symp. Quant. Biol. L1:263-273.

19. Chomczynski, P., and N. Sacchi. 1987. Single-step method of RNA isolation by acid guanidinium thiocyanate-phenol-chloroform extraction. Anal. Biochem. 162:156-159.

20. Lewis, R. V., A: S. Stern, S. Kimura, J. Rossier, S. Stein, and S. Udenfriend. 1980. An about 50,000-dalton protein in adrenal medulla: a common precursor of [met]- and [leu]enkephalin. Science (Wash. DC). 208:1459-1461.

21. Fischer-Colbrie, R., A. Iacangelo, and L. E. Eiden. 1988. Neural and humoral factors separately regulate neuropeptide $\mathrm{Y}$, enkephalin, and chromo- granin A and B mRNA levels in rat adrenal medulla. Proc. Natl. Acad. Sci. USA. 85:3240-3244.

22. Udenfriend, S., and D. L. Kilpatrick. 1984. Proenkephalin and the products of its processing: chemistry and biology. Peptides. 6:25-68.

23. Lolait, S. J., A. T. W. Lim, B. H. Toh, and J. W. Funder. 1984. Immunoreactive $\beta$-endorphin in a subpopulation of mouse macrophages. J. Clin. Invest. 73:277-280.

24. Lolait, S. J., J. A. Clements, A. J. Markwick, C. Cheng, M. McNally, A. I. Smith, and J. W. Funder. 1986. Proopiomelanocortin messenger ribonucleic acid and posttranslational processing of beta endorphin in spleen macrophages. $J$. Clin. Invest. 77:1776-1779.

25. Sakamoto, M., K. Nakao, T. Yoshimasa, Y. Ikeda, M. Suda, K. Takasu, S. Shimbo, N. Yanaihara, and H. Imura. Occurrence of methionine-enkephalin$A R G^{6}-$ GLY $^{7}-$ LEU $^{8}$ with methionine-enkephalin, leucine-enkephalin and methionine-enkephalin-ARG ${ }^{6}-\mathrm{PHE}^{7}$ in human gastric antrum. J. Clin. Endocrinol. Metab. 56:202-204.

26. Kilpatrick, D. L., T. Taniguchi, B. N. Jones, A. S. Stern, J. E. Shively, J. Hullihan, S. Kimura, S. Stein, and S. Udenfriend. 1981. A highly potent 3200 dalton adrenal opioid peptide that contains both a [Met]- and [Leu]enkephalin sequence. Proc. Natl. Acad. Sci. USA. 78:3265-3268.

27. Saland, L. C., D. E. Van Epps, E. Ortiz, and A. Samora. 1983. Acute injections of opiate peptides into the rat cerebral ventricle: a macrophage-like cellular response. Brain. Res. Bull. 10:523-528.

28. Kuis, W., P. M. Villiger, and M. Lotz. 1990. Enkephalin gene expression and peptide production in articular tissues. Arthritis Rheum. 33:s (Abstr.) 